\title{
Adjusting for 30-hour undigested neutral detergent fiber in substitution of wheat straw and beet pulp for alfalfa hay and corn silage in the diet of high-producing cows
}

\author{
A. Kahyani, ${ }^{1 *}$ G. R. Ghorbani, ${ }^{1}$ M. Alikhani, ${ }^{1}$ E. Ghasemi, ${ }^{1}$ A. Sadeghi-Sefidmazgi, ${ }^{1}$ and S. M. Nasrollahi ${ }^{2}$ \\ ${ }^{1}$ Department of Animal Sciences, College of Agriculture, Isfahan University of Technology, Isfahan 84156-83111, Iran \\ ${ }^{2}$ Young Researchers Club, Khorasgan (Isfahan) Branch, Islamic Azad University, Isfahan 81595-185, Iran
}

\section{ABSTRACT}

This study examined the feeding effects of wheat straw (WS) and beet pulp (BP) substituted for corn silage (CS) and alfalfa hay (AH) based on forage 30-h undigested neutral detergent fiber $\left(\mathrm{uNDF}_{30}\right)$ on lactation performance in high-producing dairy cows. Twelve multiparous (body weight $=611 \pm 31 \mathrm{~kg}$, days in milk $=97 \pm 13 ; 51 \pm 3 \mathrm{~kg} / \mathrm{d}$ of milk; mean \pm standard error) Holstein cows were used in a replicated $3 \times 3$ Latin square design with 28 -d periods. Three treatments were established by substituting WS for CS and AH such that the concentration of forage $\mathrm{uNDF}_{30}$ in all diets was the same. The treatments were (1) $0 \%$ forage $\mathrm{uNDF}_{30}$ from WS (WS0; control), (2) $50 \%$ forage $\mathrm{uNDF}_{30}$ from WS (WS50), and (3) $100 \%$ forage $\mathrm{uNDF}_{30}$ from WS (WS100). Beet pulp was added in the straw diets to achieve similar dietary neutral detergent fiber digestibility after 30 -h incubation $\left(\mathrm{NDFD}_{30}\right)$. The 3 diets were similar in forage $\mathrm{uNDF}_{30}$ ( $14 \%$ of dry matter), total $\mathrm{uNDF}_{30}(\sim 18.5 \%$ of dry matter $)$, and $\mathrm{NDFD}_{30}$ (approximately $42 \%$ of neutral detergent fiber). The substitution of WS and BP for AH and CS decreased the proportion of forage $(40,31$, and $22.3 \%$ of dry matter) and forage neutral detergent fiber $(21.2,19.7$, and $18.3 \%$ of dry matter) for WS0, WS50, and WS100, respectively, in the diet. However, the substitution linearly increased mean rumen $\mathrm{pH}(5.90,6.09$, and 6.28 for WS0, WS50, and WS100, respectively), digestibility of nutrients, and selection for long particles of diets without affecting dry matter intake. The substitution also linearly increased cholesterol and blood urea nitrogen concentration in the blood. Milk fat percentage, fat production, fat:protein ratio, and milk urea nitrogen increased linearly when treatments changed from WS0 to WS100, whereas the production of energy-corrected milk (ECM) was not affected by the treatments. Milk yield and milk protein yield were affected in a curvi-

Received September 23, 2018.

Accepted April 15, 2019.

*Corresponding author: ali.kahyani@gmail.com linear manner and were lower in WS100 than other treatments. The efficiency of ECM production linearly increased in the diet with higher inclusion of WS and $\mathrm{BP}$ substitution in the diet $(1.66,1.70$, and 1.72 for WS0, WS50, and WS100, respectively), but body weight, body weight change, and backfat thickness of cows were not different among treatments. In conclusion, the substitution of WS and BP for CS and AH with fixed $\mathrm{uNDF}_{30}$ improved feed efficiency and rumen $\mathrm{pH}$, decreased milk and protein yield, and did not affect ECM yield.

Key words: undigestible neutral detergent fiber, forage source, wheat straw, beet pulp, dairy cow

\section{INTRODUCTION}

Meeting the high-producing dairy cow's requirement for forage fiber is critical to maintain rumen function, milk fat percentage, and overall animal health. Incorporation of highly digestible NDF in corn silage (CS) and alfalfa hay $(\mathbf{A H})$ in the diet has the potential to improve DMI and milk production (Ferraretto et al., 2015). However, availability of high quality forages is sometimes limited because of droughts and insufficient land base on individual farms. Small-grain straw, in particular wheat straw (WS), is an available fiber source that is produced as a byproduct of wheat grain production $(\sim 750$ million metric tons according to FAOSTAT, 2016). A considerable amount of research has evaluated the effect of replacing AH or CS with WS on a DM (Wang et al., 2014; Ghasemi et al., 2016), NDF (Poore et al., 1991), or forage NDF (Eastridge et al., 2009) basis. Previous research has indicated that high-WS diets generally limit digestibility, DMI, and consequently milk production in high-producing dairy cows (Poore et al., 1991; Eastridge et al., 2009; Wang et al., 2014).

The by-product WS with a high effective fiber content is a poor source of many nutrients that can be easily supplied from concentrate mixtures (NRC, 2001). A primary limitation of WS is that NDF digestibility (NDFD) can be low (McCartney et al., 2006; Raf- 
frenato et al., 2018), which can cause a longer retention time in the rumen and lower DMI for dairy cows (Oba and Allen, 1999). The amount of potentially digestible NDF (pdNDF) can be estimated by undigested NDF [measured by after 240 -h of in vitro $\left(\mathbf{u N D F}_{\mathbf{2 4 0}}\right)$ or 288 -h in situ $\left(\mathbf{u N D F}_{288}\right)$ incubation], and its rate of digestion (Bender et al., 2016; Mertens, 2016). Raffrenato et al. (2019) showed that values of slow and fast digestible NDF and $\mathrm{uNDF}_{240}$ varied among WS, $\mathrm{AH}$, and CS. A simple and fast method for evaluation of NDFD has been established as 30 or $48 \mathrm{~h}$ in vitro or in situ incubation, and has been shown to have a high coefficient of correlation with true digestibility $\left(\mathrm{R}^{2}>\right.$ 0.90; Spanghero et al., 2010). The undigested NDF pool after 30 -h incubation $\left(\mathbf{u N D F}_{\mathbf{3 0}}\right)$ as well as NDF digestibly after 30 -h incubation $\left(\mathbf{N D F D} \mathbf{D}_{\mathbf{3 0}}\right)$ has been related to fiber digestibility (Oba and Allen, 1999), pdNDF digestion rate (Lopes et al., 2015), and intake potential (Nair et al., 2016).

We hypothesized that if the contents of forage $\mathrm{uNDF}_{30}$ and diet $\mathrm{NDFD}_{30}$ are properly balanced, WS may be successfully used to replace high-quality forages without affecting DMI in lactating dairy cows. Appropriate balance can be achieved by using WS in combination with a highly digestible fiber sources such as beet pulp (BP). Beet pulp is an excellent source of digestible fiber with a rapid digestion rate (NRC, 2001). Furthermore, the use of this by-product with WS can partially compensate the dietary energy deficiency without increasing cereal grain or starch level, which may negatively affect fiber digestibility (Firkins, 1997). Therefore, the objective of the current study was to evaluate the substitution effect of WS and BP for $\mathrm{AH}$ and $\mathrm{CS}$ with fixed forage $\mathrm{uNDF}_{30}$ and dietary $\mathrm{NDFD}_{30}$ on feed intake, ruminal $\mathrm{pH}$, nutrient digestion, blood metabolites, and milk production of lactating dairy cows.

\section{MATERIALS AND METHODS}

The experiment was conducted at the dairy facilities of the Lavark Research Station (Isfahan University of Technology, Isfahan, Iran). Animals were cared for according to the guidelines of the Iranian Council of Animal Care (1995) and the experiment was approved by the Institutional Animal Care Committee for Animals Used in Research.

\section{Forages Preparation and Measuring In Situ NDF Digestibility}

Alfalfa hay was chopped (Golchin Trasher Hay Co., Isfahan, Iran) with a theoretical length of cut of 15 $\mathrm{mm}$. Corn silage was harvested using a pull-type chopper (Model 965, Claas, Omaha, NE) with a 25 to 30 $\mathrm{mm}$ theoretical length-of-cut. To obtain finely chopped WS (Table 1), a threshing machine (designed to separate cereal grains from straw) with a $10-\mathrm{mm}$ theoretical length-of-cut (Golchin Trasher Hay Co., Isfahan, Iran) was used. The WS was reconstituted $24 \mathrm{~h}$ before in situ measurement and before feeding by placing the required amount of dry hay into an industrial container without mixing. Water at ambient temperature was added slowly to the WS during mixing to achieve a DM content of $25 \%$, then WS and water was transferred to airtight containers.

An in situ study was conducted to measure undigested NDF and NDFD in forages, BP, and TMR, according to the method described by Bender et al. (2016) and Donnelly et al. (2018; Table 1). Two ruminally cannulated nonlactating Holstein dairy cows were used and fed a high forage TMR diet (25\% AH, $25 \%$ CS, $25 \%$ WS, $4.2 \%$ BP, $20.8 \%$ concentrate mix; DM basis) as recommended by Krizsan and Huhtanen (2013). Dried samples were ground to pass a 1-mm Wiley mill (Arthur H. Thomas, Philadelphia, PA) screen, and 0.5 $\mathrm{g}$ of each sample was weighed into an Ankom F57 bag (Ankom Technology, Macedon, NY) with a pore size of $25 \mu \mathrm{m}$ (Bender et al., 2016). This particular bag was selected so that digestibility estimates would be comparable with previously reported methods (Bender et al., 2016; Su et al., 2017; Donnelly et al., 2018) and the result replicable for practice condition. Samples were incubated in the rumen for 30,240 , and $288 \mathrm{~h}$ in triplicate along with 3 blank bags for each time point. Blanks were sealed Ankom bags containing $0 \mathrm{~g}$ of sample to correct for any infiltration of NDF into the sample bags. After removal, samples were soaked in cold water and then were washed twice in a commercial washing machine with cold water for 12-min cycles to ensure that no residue adhered to the bag. This procedure was then duplicated in a second run. The equation (Bender et al., 2016) for correction by blank for calculation of NDF residue at each time point was

$$
\begin{gathered}
\mathrm{NDF}(\mathrm{g} / \mathrm{g} \text { of } \mathrm{DM})=[(\text { bag weight }+ \text { residue }) \\
-(\text { bag weight } \times \text { bag correction factor })] / \\
{[(\text { bag weight }+ \text { sample })-(\text { bag weight })]}
\end{gathered}
$$

The bag correction factor represents the average fractional weight change of 3 Ankom blank bags following the NDF wash procedure. The $\mathrm{uNDF}_{30}, \mathrm{uNDF}_{240}$, and $\mathrm{uNDF}_{288}$ were the NDF residues after 30, 240, and 288 $\mathrm{h}$ incubations, respectively, and NDF0h was NDF at the start of incubation. The value for NDFD at each time point was calculated as 
Table 1. Nutrient composition and particle size of forages and beet pulp [mean (SD)]

\begin{tabular}{|c|c|c|c|c|}
\hline $\begin{array}{l}\text { Item }(\% \text { of DM, unless } \\
\text { otherwise stated) }\end{array}$ & Alfalfa hay & Corn silage & Wheat straw & Beet pulp \\
\hline DM (\% of as fed) & $95.0(0.82)$ & $26.2(1.05)$ & $93.0(0.48)$ & $90.2(0.52)$ \\
\hline $\mathrm{OM}$ & $88.5(0.09)$ & $93.6(0.08)$ & $90.9(0.93)$ & $92.5(0.18)$ \\
\hline $\mathrm{CP}$ & $13.3(0.15)$ & $7.7(0.12)$ & $2.6(0.21)$ & $10.3(0.17)$ \\
\hline Ether extract & $1.38(0.07)$ & $2.47(0.27)$ & $1.37(0.10)$ & $0.63(0.07)$ \\
\hline NDF & $52.0(0.02)$ & $53.8(0.04)$ & $82.0(0.05)$ & $35.1(0.06)$ \\
\hline $\mathrm{NFC}^{1}$ & $21.8(0.43)$ & $29.6(0.74)$ & $4.9(0.25)$ & $46.5(0.35)$ \\
\hline Starch & $1.12(0.16)$ & $23.57(1.92)$ & $0.405(0.06)$ & $1.37(0.40)$ \\
\hline Sugar & $3.62(0.62)$ & $1.07(0.19)$ & $1.03(0.12)$ & $18.56(1.40)$ \\
\hline Lignin & $9.50(0.73)$ & $3.90(0.30)$ & $8.40(0.20)$ & $2.06(0.50)$ \\
\hline $\mathrm{uNDF}_{30}{ }^{2}$ & $32.0(0.99)$ & $37.3(3.70)$ & $62.4(3.65)$ & $7.7(3.56)$ \\
\hline $\mathrm{NDFD}_{30}{ }^{3}(\%$ of NDF $)$ & $38.6(1.92)$ & $30.9(4.33)$ & $25.9(2.45)$ & $78.2(3.55)$ \\
\hline $\mathrm{uNDF}_{240}$ & $27.4(0.62)$ & $12.90(0.67)$ & $27.4(0.89)$ & $2.82(0.41)$ \\
\hline $\mathrm{uNDF}_{288^{5}}$ & $27.2(0.57)$ & $12.8(0.68)$ & $26.6(0.87)$ & $2.81(0.39)$ \\
\hline $\operatorname{pdNDF}_{288}{ }^{6}(\%$ of NDF $)$ & $47.8(1.10)$ & $76.2(1.27)$ & $67.6(1.06)$ & $92.0(1.12)$ \\
\hline pdNDF $\mathrm{kd}^{7}(\% / \mathrm{h})$ & $4.59(0.06)$ & $2.08(0.06)$ & $1.69(0.07)$ & $7.24(0.04)$ \\
\hline \multicolumn{5}{|l|}{ Particle size distribution } \\
\hline$>19 \mathrm{~mm}$ & $2.00(0.00)$ & $18.3(3.30)$ & $1.00(0.00)$ & - \\
\hline 8 to $19 \mathrm{~mm}$ & $33.0(1.41)$ & $56.8(2.06)$ & $56.0(2.24)$ & - \\
\hline 1.18 to $8 \mathrm{~mm}$ & $43.3(0.50)$ & $24.0(1.41)$ & $37.2(1.64)$ & - \\
\hline$<1.18 \mathrm{~mm}$ & $21.8(1.26)$ & $0.97(0.06)$ & $6.20(1.10)$ & - \\
\hline $\mathrm{GMPL}^{8}(\mathrm{~mm})$ & $4.12(0.16)$ & $10.6(0.67)$ & $6.70(0.28)$ & - \\
\hline
\end{tabular}

${ }^{1} \mathrm{NFC}$ calculated by the difference of $100-(\% \mathrm{NDF}+\% \mathrm{CP}+\%$ fat $+\%$ ash $)$.

${ }^{2} \mathrm{uNDF}_{30}=\mathrm{NDF}$ residue after 30 -h in situ incubation.

${ }^{3} \mathrm{NDFD}_{30}=$ in situ NDF digestibility after 30 - $\mathrm{h}$ in situ incubation.

${ }^{4} \mathrm{uNDF}_{240}=\mathrm{NDF}$ residue after 240 -h in situ incubation.

${ }^{5} \mathrm{uNDF}_{288}=\mathrm{NDF}$ residue after 288 -h in situ incubation.

${ }^{6} \mathrm{pdNDF}_{288}=$ potentially digestible NDF after 288 - $\mathrm{h}$ in situ incubation.

${ }^{7}$ pdNDF $\mathrm{kd}=$ potentially digestible NDF fraction digestion rate.

${ }^{8} \mathrm{GMPL}=$ geometric mean of particle size.

$$
\begin{gathered}
\mathrm{NDFD}(\mathrm{g} / \mathrm{g} \text { of } \mathrm{NDF})= \\
(\mathrm{NDF} 0 \mathrm{~h}-\mathrm{NDF} \text { residue }) /(\mathrm{NDF} 0 \mathrm{~h}) .
\end{gathered}
$$

The potentially digestible NDF fraction $\left(\mathbf{p d N D F} \mathbf{F}_{\mathbf{2 8 8}}\right)$ was calculated as NDF - $\mathrm{uNDF}_{288}$ and its rate of degradation $(\mathbf{k d})$ was determined using NDF residue measurements at 9 time points $(6,12,24,30,36,48$, 72, 96, and 120 h; Figure 1). Natural logs of the pdNDF residue percentages were calculated. A log-residue value less than -3 was discarded as an invalid result (Bender et al., 2016). A linear regression based on the natural $\log$ residual values versus time was then fit to the data, and $\mathrm{kd}$ was determined as the slope of the regression (Donnelly et al., 2018).

\section{Animals, Experimental Design, and Treatments}

Twelve multiparous Holstein cows $(\mathrm{BW}=611 \pm 31$ $\mathrm{kg}, \mathrm{DIM}=97 \pm 13 \mathrm{~d}$, milk production $=51 \pm 3 \mathrm{~kg} / \mathrm{d}$, milk fat $=2.93 \pm 0.22 \%$, milk protein $=2.88 \pm 0.05 \%$, mean \pm SD) were used in a replicated $3 \times 3$ Latin square design with 28-d periods. Each period consisted of $21 \mathrm{~d}$ of adaptation followed by $7 \mathrm{~d}$ of data collection. Cows were housed in individual stalls $(4 \times 4 \mathrm{~m})$ within a roofed facility with open sides. Clean wood shavings and sand were used for bedding and refreshed daily. Three dietary treatments were formulated to replace $\mathrm{CS}$ and $\mathrm{AH}$ with WS on a forage $\mathrm{uNDF}_{30}$ basis as (1) $0 \%$ forage $\mathrm{uNDF}_{30}$ from WS (WS0; control); (2) $50 \%$ forage $\mathrm{uNDF}_{30}$ from WS (WS50); and (3) $100 \%$ forage $\mathrm{uNDF}_{30}$ from WS (WS100). Then, the appropriate amount of BP was added to make similar NDFD after 30 -h incubation $\left(\mathbf{N D F D}_{\mathbf{3 0}}\right)$ in the diets. Diets were formulated using the Cornell Net Carbohydrate and Protein System (CNCPS, version 5.0; Fox et al., 2004) to meet nutrient allowance for a lactating dairy cow weighing $650 \mathrm{~kg}$ and producing $45 \mathrm{~kg} / \mathrm{d}$ of milk with $3.0 \%$ milk true protein and $3.2 \%$ milk fat (Table 2). Feed was supplied twice daily at 1000 and 1800 $\mathrm{h}$ in amounts that allowed approximately $10 \%$ refusals, which were collected before each morning feeding. Each day, forages, beet pulp, and a concentrate premix were manually mixed and weighed into each cow's feed trough, and refusals were manually removed daily and weighed.

\section{Feed Intake and Chemical Analysis}

The TMR amounts delivered and refused were weighed and sampled daily for each cow during d 21 
to 28 of each period and daily DMI for each cow was calculated. Representative samples of forages (pooled within period), BP (pooled within period), treatment TMR (pooled by diet within period), and individual refusals (pooled by cow within period) were taken immediately before the morning feeding during the 7 -d collection period. All samples were immediately frozen at $-20^{\circ} \mathrm{C}$ until they were analyzed.

After thawing, the DM concentration of forages, TMR, and refusals samples was determined by drying at $60^{\circ} \mathrm{C}$ in a forced-air oven for $48 \mathrm{~h}$ (Townshend, 1995). All samples were ground using a Wiley mill through a 1-mm screen (Arthur H. Thomas, Philadelphia, PA) and analyzed for CP using the Kjeldahl method (Kjeltec 1030 Auto Analyzer, Tecator, Höganäs, Sweden; AOAC International, 2006, method 955.04), ether extract (EE; AOAC International, 2006, method 920.39), ash (AOAC International, 2006; method 942.05), and NDF using heat stable $\alpha$-amylase and sodium sulfite (Van Soest et al., 1991). The samples of forages, BP, and TMR were also analyzed for the amount of starch (Zhu et al., 2016) and sugar (Dubois et al., 1956). Acid detergent lignin was determined using method (AOAC International, 2006; method 973.18), modified to use 1.0 g per sample in each Ankom F57 bag (Ankom Technology, Macedon, NY). Percentage of NFC was calculated as

$$
100-(\mathrm{CP}+\mathrm{NDF}+\mathrm{EE}+\text { ash }) .
$$

\section{Particle Size Measurement and Sorting Activity}

For $6 \mathrm{~d}$ during d 22 to 27 of the study, samples of forages, TMR, and orts were collected daily for determination of particle size. Particle size was measured in triplicate using the Penn State Particle Separator equipped with 3 sieves and a bottom pan (Kononoff, 2002). After sieving, samples were placed in a forced air oven at $60^{\circ} \mathrm{C}$ to determine $\mathrm{DM}$ of each sieved fraction. Sorting of particles was determined from the actual intake of each fraction compared with the predicted intake of the same fraction had the diet been consumed as formulated (Leonardi and Armentano, 2003). A sorting index score was calculated for each fraction as the percentage of actual intake compared with the predicted intake. Values equal to $100 \%$ indicated no sorting, whereas values $<100 \%$ indicated selective refusals (sorting against), and $>100 \%$ indicated preferential consumption (sorting for).



Figure 1. The in situ NDF digestibility (NDFD) of alfalfa hay, corn silage, wheat straw, and beet pulp incubated in the rumen for 6 , 12 , $24,30,36,48,72,96,120,240$, and $288 \mathrm{~h}$. 


\section{Rumen pH and In Vivo Digestibility Measurements}

On d 28 of each period, $4 \mathrm{~h}$ after the morning feeding, rumen fluid (approximately $3 \mathrm{~mL}$ ) from the ventral sac was sampled via rumenocentesis (Nordlund and Garrett, 1994). The $\mathrm{pH}$ of the ruminal fluid was immediately determined using a portable digital pH meter (HI 8318, Hanna Instruments, Cluj-Napoca, Romania).

Six fecal grab samples were collected from each cow at 0030,0830 , and 1630 of d 25 and 26 to represent the $24-\mathrm{h}$ feeding cycle. The 6 samples were composited for each cow in each period and analyzed for nutrient digestibility. Apparent total-tract digestibility of nutrients was determined using $\mathrm{uNDF}_{288}$ as an internal marker.

\section{Blood Sampling and Analyses}

On d 27 of each period, $4 \mathrm{~h}$ after the morning feeding, blood samples $(7 \mathrm{~mL})$ were collected from the coccygeal vein using an evacuated tube without anticoagulant. Blood samples were placed on ice immediately after collection and centrifuged at $3,000 \times g$ for $15 \mathrm{~min}$ at $4^{\circ} \mathrm{C}$. Serum was separated and stored in plastic tubes and frozen at $-10^{\circ} \mathrm{C}$ until analysis. The concentrations

Table 2. Ingredient composition of dietary treatments as $\%$ of DM [values in parentheses are \% of forage 30-h undigested neutral detergent fiber $\left(\mathrm{uNDF}_{30}\right)$ ]

\begin{tabular}{|c|c|c|c|}
\hline \multirow[b]{2}{*}{ Item } & \multicolumn{3}{|c|}{$\operatorname{Diet}^{1}$} \\
\hline & WS0 & WS50 & WS100 \\
\hline Wheat straw & 0.0 & $11.16(50)$ & $22.32(100)$ \\
\hline Alfalfa hay & $18.0(41)$ & $7.08(16)$ & 0.0 \\
\hline Corn silage & $22.0(59)$ & $12.68(34)$ & 0.0 \\
\hline Beet pulp & 2.00 & 7.60 & 12.40 \\
\hline Barley grain & 16.0 & 16.0 & 16.0 \\
\hline Corn dry finely ground & 20.0 & 20.0 & 20.0 \\
\hline Meat meal & 3.80 & 3.80 & 3.80 \\
\hline Soybean meal & 11.2 & 14.0 & 16.84 \\
\hline Soybean extruded & 2.00 & 2.00 & 2.00 \\
\hline Canola meal & 0.40 & 0.40 & 0.40 \\
\hline Sodium bicarbonate & 1.00 & 1.00 & 1.00 \\
\hline Calcium carbonate & 0.52 & 0.56 & 0.52 \\
\hline Dicalcium phosphate & 0.08 & 0.16 & 0.40 \\
\hline Magnesium oxide & 0.16 & 0.20 & 0.24 \\
\hline Minvit $^{2}$ & 0.80 & 0.80 & 0.80 \\
\hline Salt & 0.20 & 0.20 & 0.20 \\
\hline Energy Booster & 1.84 & 2.36 & 3.08 \\
\hline
\end{tabular}

${ }^{1}$ Experimental diets were different $\mathrm{uNDF}_{30}$ adjusted levels of wheat straw (WS): (1) WS0 $=0 \%$ forage $\mathrm{uNDF}_{30}$ of WS, (2) WS50 $=50 \%$ forage $\mathrm{uNDF}_{30}$ from WS, and (3) $\mathrm{WS} 100=100 \%$ forage $\mathrm{uNDF}_{30}$ from WS.

${ }^{2}$ Contained $2.5 \mathrm{~g} / \mathrm{kg}$ of $\mathrm{Fe}, 1.6 \mathrm{~g} / \mathrm{kg}$ of $\mathrm{Cu}, 3 \mathrm{~g} / \mathrm{kg}$ of $\mathrm{Mn}, 0.1 \mathrm{~g} / \mathrm{kg}$ of Co, $20 \mathrm{~g} / \mathrm{kg}$ of Mg, $5 \mathrm{~g} / \mathrm{kg}$ of Zn, $0.04 \mathrm{~g} / \mathrm{kg}$ of Se, $0.10 \mathrm{~g} / \mathrm{kg}$ of I, $3 \mathrm{~g} /$ $\mathrm{kg}$ of monensin, $50 \mathrm{~g} / \mathrm{kg}$ of Mycosorb, 10,000,000 IU $/ \mathrm{kg}$ of vitamin A, $250,000 \mathrm{IU} / \mathrm{kg}$ of vitamin $\mathrm{D}$, and $5,000 \mathrm{IU} / \mathrm{kg}$ of vitamin E. Minvit: vetaque, Sirjan, Iran; mycosorb: AIItech Inc., Nicholasville, KY; energy booster: Energizer RP-10, IFFCO, Johor, Malaysia. of serum glucose, cholesterol, BUN, high-density lipoprotein cholesterol, triglyceride, total protein, albumin, creatinine, aspartate aminotransferase, and alkaline phosphatase were measured by an autoanalyzer (Abbott Alcyon 300, Abbott Laboratories, Chicago, IL) using commercial kits (Pars Azmoon Co., Tehran, Iran) according to the manufacturer's instructions. The analyzer was calibrated and controls assayed daily according to the manufacturer's instructions to ensure acceptable assay performance. Serum BHB, fatty acids, and total antioxidant capacity were determined by commercial colorimetric kits (Randox Laboratories Ltd., Ardmore, UK) using the same autoanalyzer. The concentration of serum malondialdehyde (MDA) was determined by the thiobarbituric acid reacting substances method, in which the absorbance of a colored complex that is formed from the reaction of MDA with 2-thiobarbituric acid in acid is measured at $532 \mathrm{~nm}$ (Wullepit et al., 2012). Globulin concentrations were calculated by subtracting albumin concentrations from total protein.

\section{Milk Yield and Components, BW, and BFT}

Cows were milked 3 times daily at 0100, 0900, and $1700 \mathrm{~h}$ in a herringbone milking parlor. Milk yield for all cows was recorded and sampled at each milking during d 21 to 28 of each period. Milk samples were preserved with potassium dichromate, stored at $4^{\circ} \mathrm{C}$, and submitted to the Isfahan University of Technology Central Milk Testing Laboratory (Isfahan, Iran) for fat, protein, and lactose analyses using an infrared analyzer (MilkoScan 134 BN, Foss Electric, Hillerød, Denmark; AOAC International, 2002; method 972.16). The MUN content was also determined by enzymatic assay (Wilson et al., 1998). Milk was centrifuged at $1,200 \times g$ for 15 min at $4^{\circ} \mathrm{C}$, and the fat was removed. The defatted milk was then thoroughly mixed and deproteinized by mixing $0.2 \mathrm{~mL}$ of defatted milk with $1.8 \mathrm{~mL}$ of cold trichloroacetic acid and allowing the mixture to stand for $5 \mathrm{~min}$. The sample was then centrifuged at $1,200 \times g$ for $5 \mathrm{~min}$ at $20^{\circ} \mathrm{C}$, and $0.2 \mathrm{~mL}$ of the clear supernatant was analyzed for MUN using a colorimetric diacetyl monoxine procedure. Milk yield was corrected for milk components as ECM (Tyrrell and Reid, 1965):

$$
\begin{gathered}
\text { ECM }=0.3246 \text { milk yield }+12.96 \text { fat yield } \\
+7.04 \text { protein yield. }
\end{gathered}
$$

Cows were weighed at the beginning (d 1) and the end (d 28) of each period. Backfat thickness (BFT) was measured on d 28 according to Schroder and Staufenbiel (2006) using a portable B-mode ultrasound generator 
(SonoVet 600V, BCF Technology Ltd., West Lothian, Scotland, UK) with a linear transducer and frequency between 5.0 and $6.5 \mathrm{MHz}$.

\section{Statistical Analyses}

Data were analyzed using the mixed model procedure of SAS (Proc Mixed; SAS Institute, 2002) to account for effects of square, cow within square, and treatment. The treatment, square, and period were considered as fixed effects; cow within square was considered a random effect. The mathematical expression of the model can be as below:

$$
\mathrm{Y}_{\mathrm{ijkl}}=\mu+\mathrm{P}_{\mathrm{i}}+\mathrm{S}_{\mathrm{j}}+\mathrm{C}(\mathrm{S})_{\mathrm{kj}}+\mathrm{T}_{\mathrm{l}}+\mathrm{e}_{\mathrm{ijk} \mathrm{k}},
$$

where $Y_{\mathrm{ijkl}}=$ the dependent variable, $\mu=$ the population mean, $\mathrm{P}_{\mathrm{i}}=$ the fixed effect of period $\mathrm{i}, \mathrm{S}_{\mathrm{j}}=$ the fixed effect of square $\mathrm{j}, \mathrm{C}(\mathrm{S})_{\mathrm{kj}}=$ the random effect of cow $\mathrm{k}$ within square $\mathrm{j}, \mathrm{T}_{1}=$ the fixed effect of treatment $\mathrm{l}$, and $\mathrm{e}_{\mathrm{ijkl}}=$ the random residual error, assumed to be normally distributed. Estimation method was REML and the degrees of freedom method was KenwardRogers. Polynomial orthogonal contrasts were used to test the linear and quadratic models. Additionally, the differences among the treatments were evaluated using a multiple comparison test following the Tukey-Kramer method. Statistical significance of any main effect was declared at $P \leq 0.05$, and tendencies were discussed at $0.05 \leq P \leq 0.10$.

\section{RESULTS}

\section{Forages and Diets}

Nutrient composition, in situ NDFD, and particle size distribution of forages and diets are shown in Tables 1 and 3 . Wheat straw had the greatest amount of $\mathrm{uNDF}_{30}$ (62.4\% of DM), followed by CS (37.3\%), AH (32.0\%), and $\mathrm{BP}(7.7 \%)$. Inversely, $\mathrm{NDFD}_{30}(\%$ of $\mathrm{NDF})$ measured 25.9, 30.9, 38.6, and 78.2 for WS, CS, AH, and $\mathrm{BP}$, respectively. The amount of $\mathrm{uNDF}_{288}$ (DM basis) was lower in CS (12.8\%) than $\mathrm{AH}(27.2 \%)$ with no difference between AH and WS. Moreover, notably, the finely chopped WS produced a geometric mean particle size (GMPL) of $6.70 \mathrm{~mm}$ that was higher than $\mathrm{AH}$ (4.12 mm) and lower than CS (10.6 mm).

As intended, the 3 dietary treatments were designed to have a same forage $\mathrm{uNDF}_{30}$ of $13.9 \pm 0.05 \%$, but were different in forage NDF with amounts of 21.2, 19.7, and $18.3 \%$ for WS0, WS50 and WS100, respectively (Table 3). Additionally, measured $\mathrm{CP}$ and predicted $\mathrm{NE}_{\mathrm{L}}$ contents were similar among the 3 dietary treatments. The treatments resulted in a similar dietary $\mathrm{uNDF}_{30}$ $(\sim 18.5 \%$ of $\mathrm{DM})$ and $\mathrm{NDFD}_{30}(\sim 42 \%$ of $\mathrm{NDF})$, whereas the content of starch (from 29.0 to $23.5 \%$ ), ADL (2.4 to $1.5 \%)$, and $\mathrm{uNDF}_{288}(10.1$ to $8.5 \%)$ were decreased as level of WS inclusion elevated. The percentage of particles $>19 \mathrm{~mm}(4.02,2.20$, and 0.50) and GMPL (3.84, 3.72 , and $3.54 \mathrm{~mm}$ ) of the TMR was also decreased as WS was increased in the diet.

\section{Intake, Sorting Activity, Rumen $\mathrm{pH}$, and Apparent Digestibility}

The substitution of WS and BP for CS and $\mathrm{AH}$ in the diet did not affect the intake of DM, NDF, and uNDF30, but decreased the intake of $\mathrm{uNDF}_{240}$ and $\mathrm{uNDF}_{288}$, and increased intake of $\mathrm{pdNDF}_{288}$ (Table 4). However, sorting in favor of long particles (particles $\leq 19 \mathrm{~mm}$ and $8-19 \mathrm{~mm}$ ) increased as the amount of WS and $\mathrm{BP}$ increased in the diet. Also, ruminal $\mathrm{pH}$ was $5.90,6.09$, and 6.28 for WS0, WS50, and WS100, respectively $(P<0.01$; Table 4$)$. Furthermore, increased inclusions of WS and BP curvilinearly increased the digestibility of $\mathrm{DM}(62.8,63.4$, and $68.0 \%)$ and $\mathrm{OM}$, and linearly increased the digestibility of EE, NDF (32.9, 37.1, and 45.1), pdNDF and CP $(P<0.01)$, but did not affect the digestibility of NFC (Table 4). The digestibility of pdNDF was 11 units $(0.95 \mathrm{~kg} / \mathrm{d})$ greater in WS100 (59\%) than in WS0 (48\%).

\section{Blood Metabolites}

Treatments did not affect glucose, high-density lipoprotein, triglyceride, or fatty acid concentration in the blood, but increased inclusions of WS and BP linearly increased cholesterol $(250,259$, and $283 \pm 11.7 \mathrm{mg} / \mathrm{dL}$; $P=0.02)$, BHB $(0.55,0.64,0.72 \pm 0.06 \mathrm{mg} / \mathrm{dL} ; P=$ $0.03)$, and BUN $(16.7,18.4$, and $22.8 \pm 0.76 \mathrm{mg} / \mathrm{dL} ; P$ $<0.01)$ concentrations in blood for WS0, WS50, and WS100, respectively. The concentration of BUN was $36.5 \%$ greater in WS100 than WS0. The concentration of albumin was linearly increased $(3.35,3.33$, and 3.57 $\pm 0.07 \mathrm{mg} / \mathrm{dL}$ for WS0, WS50, and WS100, respectively; $P=0.05$ ) with increased inclusions of $\mathrm{WS}$ and $\mathrm{BP}$, whereas the concentration of globulin remained unaffected. The activity of aspartate aminotransferase and alkaline phosphatase enzymes in the plasma, as well as the concentration of total antioxidant capacity and MDA, were not affected by treatments.

\section{Milk Yield and Component, Feed Efficiency, and BW Change}

Milk yield was affected in a curvilinear manner, with the WS100 diet lower than other treatments (Table 5), but the yield of ECM was not affected by the treat- 
ments. The fat yield, fat percentage, MUN, and fat: protein ratio increased linearly with increasing WS and $\mathrm{BP}$, but protein and lactose contents were decreased. Similar to milk yield, protein and lactose yield were affected curvilinearly, and were lower in WS100 than other treatments.

The efficiency of milk yield was not affected by the treatments, but the efficiency of ECM linearly increased as the level of WS and BP increased in the diet. A 0.06 unit improvement occurred in feed efficiency [ECM $(\mathrm{DMI})^{-1}$ ] when WS0 (1.66) was compared with WS100 (1.72). Body weight, BFT, and BW change were unaffected with the change in $\mathrm{uNDF}_{30}$ adjusted level of WS.

\section{DISCUSSION}

The present study attempts to investigate the outcome of using $\mathrm{uNDF}_{30}$ and $\mathrm{NDFD}_{30}$ for balancing ratios of high- or low-quality forages and by products in dairy cow diets. Wheat straw contained both the highest concentration of $\mathrm{uNDF}_{30}$ and lowest $\mathrm{NDFD}_{30}$. On the other hand, BP as a nonforage fiber source had the lowest amount of $\mathrm{uNDF}_{30}$ and the highest $\mathrm{NDFD}_{30}$. Thus, feeding WS along with BP not only resulted in the same forage $\mathrm{uNDF}_{30}$, but also in the same dietary $\mathrm{uNDF}_{30}$ and $\mathrm{NDFD}_{30}$. Nevertheless, concentration of dietary $\mathrm{uNDF}_{288}$ linearly decreased and $\mathrm{pdNDF}_{288}$ increased as the level of BP and WS increased. The performance results presented herein indicate that WS and $\mathrm{BP}$ substitution for $\mathrm{CS}$ and $\mathrm{AH}$ formulated on the basis of the method did not have a negative effect on lactation performance, but improved production efficiency.

Dry matter intake and the intake of $\mathrm{uNDF}_{30}$ were not different among treatments, which was expected because the diets were formulated for similar levels of forage $\mathrm{uNDF}_{30}$. However, intake of $\mathrm{uNDF}_{288}$ or $\mathrm{uNDF}_{240}$ were decreased, and this relates to a lower proportion in the formulated diets. Replacing forage with WS on a DM or NDF basis has not been found to affect DMI in previous studies (Poore et al., 1991; Eastridge et al.,

Table 3. Nutrient composition and particle size of dietary treatments [mean (SD)]

\begin{tabular}{|c|c|c|c|}
\hline \multirow{2}{*}{$\begin{array}{l}\text { Item (\% of DM, unless } \\
\text { otherwise stated) }\end{array}$} & \multicolumn{3}{|c|}{ Diet $^{1}$} \\
\hline & WS0 & WS50 & WS100 \\
\hline $\mathrm{DM}(\%$ of as fed) & $46.6(1.86)$ & $46.8(2.71)$ & $44.8(2.91)$ \\
\hline OM & $91.4(0.15)$ & $91.9(0.14)$ & $91.8(0.09)$ \\
\hline $\mathrm{CP}$ & $16.3(0.18)$ & $16.1(0.07)$ & $16.5(0.50)$ \\
\hline Ether extract & $4.57(0.28)$ & $5.06(0.18)$ & $5.47(0.11)$ \\
\hline $\mathrm{NDF}$ & $31.4(1.00)$ & $32.1(1.52)$ & $32.5(1.43)$ \\
\hline $\mathrm{NFC}^{2}$ & $39.1(0.84)$ & $38.6(1.54)$ & $37.4(2.12)$ \\
\hline Starch & $29.02(1.47)$ & $26.78(1.22)$ & $23.58(1.08)$ \\
\hline Sugar & $3.12(0.45)$ & $3.95(0.49)$ & $4.68(0.63)$ \\
\hline Lignin & $2.41(0.13)$ & $2.08(0.14)$ & $1.51(0.10)$ \\
\hline Forage NDF & $21.2(0.21)$ & $19.7(0.10)$ & $18.3(0.09)$ \\
\hline $\mathrm{NE}_{\mathrm{L}}^{3}(\mathrm{Mcal} / \mathrm{kg}$ of DM) & 1.65 & 1.66 & 1.65 \\
\hline Forage $\mathrm{uNDF}_{30}$ & $14.0(0.63)$ & $13.9(0.46)$ & $13.9(0.66)$ \\
\hline $\mathrm{uNDF}_{30} 4$ & $18.2(1.32)$ & $18.3(1.41)$ & $19.0(1.17)$ \\
\hline $\mathrm{NDFD}_{30}{ }^{30}(\%$ of NDF $)$ & $42.2(1.76)$ & $43.0(3.23)$ & $41.7(2.38)$ \\
\hline $\mathrm{uNDF}_{240}{ }^{6}$ & $10.21(0.40)$ & $9.85(0.46)$ & $8.75(0.54)$ \\
\hline $\mathrm{uNDF}_{288} 7$ & $10.1(0.45)$ & $9.52(0.43)$ & $8.48(0.67)$ \\
\hline $\operatorname{pdNDF}_{288}{ }^{8}(\%$ of NDF $)$ & $67.8(1.99)$ & $70.3(2.01)$ & $73.9(1.60)$ \\
\hline pdNDF kd ${ }^{9}(\% / \mathrm{h})$ & $2.42(0.11)$ & $2.60(0.14)$ & $3.10(0.14)$ \\
\hline$>19 \mathrm{~mm}$ & $4.02(0.86)$ & $2.20(0.20)$ & $0.50(0.20)$ \\
\hline 19 to $8 \mathrm{~mm}$ & $23.1(1.11)$ & $23.7(1.52)$ & $21.1(2.14)$ \\
\hline 1.18 to $8 \mathrm{~mm}$ & $51.5(0.47)$ & $52.7(1.27)$ & $58.2(1.50)$ \\
\hline$<1.18 \mathrm{~mm}$ & $21.4(2.28)$ & $21.4(0.08)$ & $20.3(2.48)$ \\
\hline $\mathrm{GMPL}^{10}(\mathrm{~mm})$ & $3.84(0.18)$ & $3.72(0.08)$ & $3.54(0.08)$ \\
\hline
\end{tabular}

${ }^{1}$ Experimental diets were different $\mathrm{uNDF}_{30}$ adjusted levels of wheat straw (WS): (1) WS0 $=0 \%$ forage $\mathrm{uNDF}_{30}$ from WS, (2) $\mathrm{WS} 50=50 \%$ forage $\mathrm{uNDF}_{30}$ from WS, and (3) $\mathrm{WS} 100=100 \%$ forage $\mathrm{uNDF}_{30}$ from WS.

${ }^{2} \mathrm{NFC}$ calculated by the difference of $100-(\% \mathrm{NDF}+\% \mathrm{CP}+\%$ fat $+\%$ ash $)$.

${ }^{3}$ Based on tabular values (Cornell Net Carbohydrate and Protein System; Fox et al., 2004).

${ }^{4} \mathrm{uNDF}_{30}=\mathrm{NDF}$ residue after 30 - $\mathrm{h}$ in situ incubation.

${ }^{5} \mathrm{NDFD}_{30}=$ in situ NDF digestibility after 30 -h in situ incubation.

${ }^{6} \mathrm{uNDF}_{240}=\mathrm{NDF}$ residue after 240 -h in situ incubation.

${ }^{7} \mathrm{uNDF}_{288}=$ NDF residue after 288 -h in situ incubation.

${ }^{8} \mathrm{pdNDF}_{288}=$ potentially digestible NDF after 288 -h in situ incubation.

${ }^{9} \mathrm{pdNDF} \mathrm{kd}=$ potentially digestible NDF fraction digestion rate.

${ }^{10} \mathrm{GMPL}=$ geometric mean of particle size. 
Table 4. Intake, rumen $\mathrm{pH}$, and nutrient digestibility of dairy cows fed different forage 30 -h undigested neutral detergent fiber $(\mathrm{uNDF}$ 30) from wheat straw (WS) or alfalfa hay and corn silage

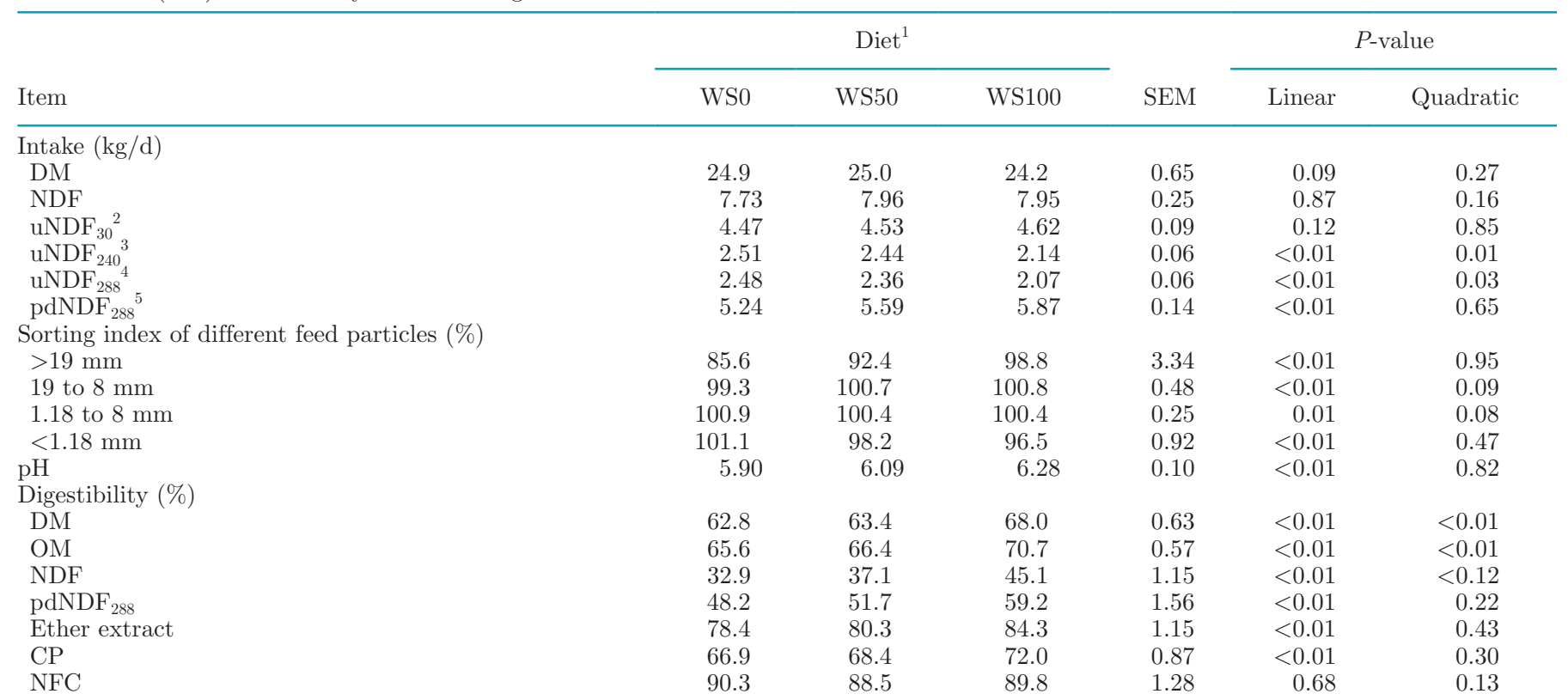

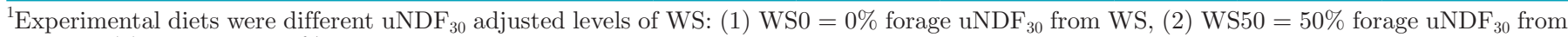
$\mathrm{WS}$, and (3) $\mathrm{WS} 100=100 \%$ forage $\mathrm{uNDF}_{30}$ from WS.

${ }^{2} \mathrm{uNDF}_{30}=\mathrm{NDF}$ residue after $30-\mathrm{h}$ in situ incubation.

${ }^{3} \mathrm{uNDF}_{240}=\mathrm{NDF}$ residue after 240 -h in situ incubation.

${ }^{4} \mathrm{uNDF}_{288}=\mathrm{NDF}$ residue after 288 -h in situ incubation.

${ }^{5} \mathrm{pdNDF}_{288}=$ potentially digestible NDF after 288 -h in situ incubation.

Table 5. Milk production and composition, feed efficiency, and BW change of dairy cows fed adjusted amount of forage 30-h undigested neutral detergent fiber $\left(\mathrm{uNDF}_{30}\right)$ from wheat straw (WS) or alfalfa hay and corn silage

\begin{tabular}{|c|c|c|c|c|c|c|}
\hline \multirow[b]{2}{*}{ Item } & \multicolumn{3}{|c|}{$\operatorname{Diet}^{1}$} & \multirow[b]{2}{*}{ SEM } & \multicolumn{2}{|c|}{$P$-value } \\
\hline & WS0 & WS50 & WS100 & & Linear & Quadratic \\
\hline \multicolumn{7}{|l|}{ Yield $(\mathrm{kg} / \mathrm{d})$} \\
\hline Milk yield & 46.3 & 46.7 & 44.4 & 0.76 & $<0.01$ & 0.01 \\
\hline $\mathrm{ECM}^{2}$ & 41.7 & 42.9 & 42.1 & 0.99 & 0.58 & 0.13 \\
\hline Fat & 1.32 & 1.39 & 1.43 & 0.05 & $<0.01$ & 0.68 \\
\hline Protein & 1.36 & 1.37 & 1.28 & 0.02 & $<0.01$ & $<0.01$ \\
\hline Lactose & 2.21 & 2.21 & 2.08 & 0.04 & $<0.01$ & $<0.01$ \\
\hline \multicolumn{7}{|l|}{ Composition (\%) } \\
\hline Fat & 2.84 & 2.97 & 3.25 & 0.11 & $<0.01$ & 0.24 \\
\hline Protein & 2.94 & 2.93 & 2.90 & 0.02 & 0.02 & 0.37 \\
\hline Lactose & 4.78 & 4.75 & 4.69 & 0.04 & $<0.01$ & 0.63 \\
\hline MUN (mg/dL) & 14.44 & 13.82 & 16.50 & 0.52 & 0.01 & 0.01 \\
\hline Fat:protein & 0.96 & 1.00 & 1.11 & 0.03 & $<0.01$ & 0.12 \\
\hline \multicolumn{7}{|l|}{ Feed efficiency } \\
\hline Milk yield/DMI & 1.85 & 1.87 & 1.82 & 0.05 & 0.25 & 0.20 \\
\hline ECM/DMI & 1.66 & 1.70 & 1.72 & 0.03 & 0.01 & 0.67 \\
\hline BW (kg) & 617 & 616 & 612 & 11.72 & 0.18 & 0.69 \\
\hline BW change $(\mathrm{kg})$ & 2.66 & 0.16 & 0.15 & 3.85 & 0.65 & 0.79 \\
\hline $\mathrm{BFT}^{3}(\mathrm{~mm})$ & 29.1 & 28.8 & 28.6 & 0.96 & 0.62 & 1.00 \\
\hline
\end{tabular}

${ }^{1}$ Experimental diets were different $\mathrm{uNDF}_{30}$ adjusted levels of WS: (1) WS0 $=0 \%$ forage $\mathrm{uNDF}_{30}$ from WS, (2) $\mathrm{WS} 50=50 \%$ forage $\mathrm{uNDF}_{30}$ from WS, and (3) $\mathrm{WS}_{100}=100 \%$ forage $\mathrm{uNDF}_{30}$ from WS.

${ }^{2} \mathrm{ECM}=0.3246$ milk yield +12.96 fat yield +7.04 protein yield (Tyrrell and Reid, 1965).

${ }^{3}$ Backfat thickness (BFT) was measured using the ultrasonographic method (Schroder and Staufenbiel, 2006). 
2009; Wang et al., 2014). These authors hypothesized that finely chopped WS does not increase rumen fill, and that energy demand is the primary regulator of intake. However, Fustini et al. (2017) indicated that DMI was higher in cows fed a highly digestible forages compared with cows fed a less digestible forages, despite similar $\mathrm{uNDF}_{240}$ levels. Ferraretto et al. (2015) also reported greater DMI and milk yields by cows fed CS with higher 30 -h in vitro NDFD.

In the present study, cows fed WS0 sorted the ration, ingesting a ration smaller in particle length than offered, and this behavior linearly decreased as level of WS increased. Cows have previously been observed to sort rations against longer particles and to a greater degree when poorly digestible forage is offered (SuarezMena et al., 2013; Miller-Cushon and DeVries, 2017). Adequate forage chopping (Fustini et al., 2016) and reconstituting (Hooper and Welch, 1985; Pasha et al., 1994) have been suggested approaches to decrease sorting when poorly digestibly forage is required in dairy cow diets. Fine chopping and reconstituting of WS for $24 \mathrm{~h}$ before feeding in the present study also decreased sorting against long particles. This result agrees with the predicted consequences of optimal specific gravity, adhesion of fine concentrate particles to larger fiber particles, and uniform particle size distribution of ingested feed (Hooper and Welch, 1985; Teimouri Yansari et al., 2004; Fustini et al., 2016). Also, in agreement with these observations, Suarez-Mena et al. (2013) reported that as particle length of low-quality forage decreased, sorting against longer particles decreased linearly, and Coon et al. (2018) reported that decreasing particle size of WS can prevent sorting against long particles in dairy cows. The importance of this discussion is that dietary effective fiber is required by dairy cows to stimulate chewing, maintain optimal rumen environment, and regulate peristalsis of the gastrointestinal tract (Van Soest, 1994). Ruminal $\mathrm{pH}$ at 4-h postfeeding increased with inclusion of WS and BP in the diet. The $\mathrm{pH}$ data might not represent the time-course changes of rumen $\mathrm{pH}$ throughout a 24-h period. However, cows fed the WS diet selected for long particles and the starch level in the respective diet was lower than in the control diet. These observations agree with our observations of rumen $\mathrm{pH}$.

In the current study, the substitution of WS and BP increased digestibility of DM and most other nutrients, including NDF and pdNDF. Increased intake of pdNDF, decreased dietary particle size, and decreased lignin as well as balancing of $\mathrm{NDFD}_{30}$ of diets with $\mathrm{BP}$ can be possible reasons for enhanced fiber digestibility (Van Soest, 1994; De Veth and Kolver, 2001). However, several studies found decreased (Poore et al., 1991; Farmer et al., 2014; Wang et al., 2014) or unaffected
(Eastridge et al., 2009) nutrient digestibility with feeding WS diets substituted based on DM or NDF, and it is possible that uncontrolled $\mathrm{uNDF}_{288}$ and lignin have caused these responses. One additional difference between the present study and previous works is that inert fat, rather than grain, was used to correct for energy in WS-supplemented diets. Suppression of NDFD in low rumen $\mathrm{pH}$ condition has been well documented (Mertens, 1993; Nasrollahi et al., 2015, 2016). Of interest, the present study identified increased digestibility of pdNDF as treatment changed from WS0 to WS100. The important difference between the present study and previous works, in this case, is that BP was used to adjust the level of $\mathrm{NDFD}_{30}$ in WS diets. Inclusion of $\mathrm{BP}$ was perhaps was a primary reason for increased intake of pdNDF in WS diets. The uniform ingestion of WS and BP particles, as discussed previously in this report, also perhaps contributed to retention of digestible fiber in the rumen. The extent of fiber digestibility depends on the size of the indigestible fraction and the competition between the rate of ruminal passage and degradation (Oba and Allen, 1999). We hypothesized that increased fiber digestibility was due to the increased inclusion of highly digestible BP, and also to the increased inclusion of WS that promoted greater rumen $\mathrm{pH}$ and particle retention.

Although feeding WS as the sole forage source lowered milk yield, but did not affect the production of ECM as cows fed WS100 had higher milk fat percentage than cows fed WS0 (3.25 vs. 2.84\%). Moreover, the feed efficiency calculated as ECM/DMI improved by feeding WS in combination with BP. The substitution of WS and BP for forages was associated with greater ingestion of long particles, increased ruminal $\mathrm{pH}$, and perhaps a greater molar percentage of butyrate from feeding BP. These effects (Voelker and Allen, 2003; Nasrollahi et al., 2015, 2016), and the effects of increasing the level of dietary supplemented fat (mainly palmitic acid; Lock et al., 2013) might supply cows fed WS with greater substrates that promote milk fat production. Previous studies have generally reported that feeding high level of WS based on NDF or forage NDF decreased milk yield with no effect or a negative effect on FCM or fat production (Poore et al., 1991; Eastridge et al., 2009; Farmer et al., 2014; Wang et al., 2014). Therefore, the use of digestibility or $\mathrm{uNDF}_{30}$ index would be an advancement over using forage NDF in formulating diets with different forage qualities. Diet digestibility represents an important target for improving the efficiency of energy utilization in dairy cows (Reynolds et al., 2011). The higher nutrient digestibility partially explains the higher efficiency with WS diets compared with the control diet. Furthermore, the highly digestible sugar and soluble fiber that was sup- 
plied with BP in WS diets likely improved the supply of energy in these diets.

Blood urea nitrogen increased and milk protein production decreased with increasing levels of WS. The high concentration of BUN has been associated with reduced fertility in dairy cows (Nasrollahi, 2011), and as an indicator of low $\mathrm{N}$ efficiency (Broderick, 2006). In the present study, starch was 5.6 percentage units lower in WS100 than in the control diet (23.6 vs. 29.0\%). With similar DMI, total starch intake was $1.35 \mathrm{~kg} / \mathrm{d}$ lower in the WS100 diet than in the control diet. This low level of starch could have limited rumen microbial protein synthesis and decreased the amount of absorbed propionate from the rumen. If this conjecture is accurate, these effects could have decreased the effective insulin response to cause a decrease in milk protein synthesis (Hall and Herejk, 2001; Mahjoubi et al., 2009; Piccioli-Cappelli et al., 2014). The imbalance of rumen fermentable starch and protein in the rumen could also explain increased BUN in the WS diets. One observation in previous works that supports this hypothesis is that when an administration of WS in the diet was balanced for NFC or starch, the concentration of MUN or milk protein was unaffected (Eastridge et al., 2009), or even increased (Poore et al., 1991). On the other hand, when substituted WS was added without providing sufficient NFC or starch, the concentration of MUN increased (Farmer et al., 2014; Wang et al., 2014) and milk protein production decreased (Wang et al., 2014; Ghasemi et al., 2016). Further work seems to be needed to improve $\mathrm{N}$ efficiency and increase milk protein production from poorly digestible fiber sources such as WS by considering better synchronization of energy, total $\mathrm{N}$, and AA supply.

Finally, it should be stated that the result of the present study was dependent on specific values of $\mathrm{uNDF}_{30}$ and $\mathrm{NDFD}_{30}$ in forages and $\mathrm{BP}$. The variety, growing conditions, and harvesting conditions can all have affected these values even in the same forage types. An example of the effect of variety is that the CS used in the current study was similar in $\mathrm{NDFD}_{30}$ to WS. This observation likely is not consistent among all CS. Therefore, when applying of the results of the present study, it is highly recommended to measure $\mathrm{uNDF}_{30}$ and $\mathrm{NDFD}_{30}$ for each forage and byproduct to be used.

\section{CONCLUSIONS}

Forage fiber along with other factors plays an important role in determining fiber requirements of the lactating cow. The formulation of diets based on forage fiber digestibility (i.e., $\mathrm{uNDF}_{30}$ and $\mathrm{NDFD}_{30}$ ) is proposed as an alternative marker to forage NDF for the control of rumen fill, DMI, and performance of dairy cows. Measures of $\mathrm{uNDF}_{30}$ and $\mathrm{NDFD}_{30}$ can be used for the selection and formulation of forages with different qualities. The provision of $\mathrm{WS}$ and $\mathrm{BP}$ in place of $\mathrm{AH}$ and $\mathrm{CS}$ with fixed $\mathrm{UNDF}_{30}$ and $\mathrm{NDFD}_{30}$ had no negative effects on DMI and ECM in dairy cows. However, the substitution improved ruminal $\mathrm{pH}$, nutrient digestibility, milk fat yield, and ECM efficiency. These beneficial effects were possibly the results of a good combination of WS and BP. Therefore, BP served as an alternative to high-quality forages when WS was added to maintain uNDF30. However, feeding WS as the sole forage source, increased MUN, and decreased milk protein yield. Further studies on the supplementation of rumen available carbohydrate or RDP with WS diets are needed to optimize $\mathrm{N}$ efficiency.

\section{ACKNOWLEDGMENTS}

This manuscript is contribution no. 95816047 from the Iran National Science Foundation (Tehran, Iran). The authors are grateful to David E. Cook (BoviSync, Eden, WI) for his kindly helpful assistance in calculation of digestibility parameters and editions on the final version of this paper. We are also grateful to Lucas Krueger (Agri-King Inc., Fulton, IL) for his kindly and helpful editions on the final version of this paper. The authors also thank A. Piadeh, H. Kahyani (Isfahan, Iran), and Feed Processing Co. of Kabileh (Isfahan, Iran) for their technical assistance.

\section{REFERENCES}

AOAC International. 2002. Official Methods of Analysis. 17th ed. 1st rev. AOAC Int., Gaithersburg, MD.

AOAC International. 2006. Official Methods of Analysis. 18th ed. AOAC International, Arlington, VA.

Bender, R. W., D. E. Cook, and D. K. Combs. 2016. Comparison of in situ versus in vitro methods of fiber digestion at 120 and 288 hours to quantify the indigestible neutral detergent fiber fraction of corn silage samples. J. Dairy Sci. 99:5394-5400.

Broderick, G. A. 2006. Nutritional strategies to reduce crude protein in dairy diets. Proc. 21st Annual Southwest Nutrition and Management Conference, Tempe, AZ. Accessed Mar. 21, 2014. http:// www.dairyweb.ca/Resources/SWNMC2006/Broderick.pdf.

Coon, R. E., T. F. Duffield, and T. J. DeVries. 2018. Effect of straw particle size on the behavior, health, and production of early lactation dairy cows. J. Dairy Sci. 101:6375-6387. https://doi.org/10 $.3168 /$ jds.2017-13920.

De Veth, M. J., and E. S. Kolver. 2001. Diurnal variation in $\mathrm{pH}$ reduces digestion and synthesis of microbial protein when pasture is fermented in continuous culture. J. Dairy Sci. 84:2066-2072. https: //doi.org/10.3168/jds.S0022-0302(01)74651-6.

Donnelly, D. M., L. C. de Resende, D. E. Cook, R. H. Atalla, and D. K. Combs. 2018. Technical note: A comparison of alkali treatment methods to improve neutral detergent fiber digestibility of corn stover. J. Dairy Sci. 101:9058-9064. https://doi.org/10.3168/jds .2017-14317.

Dubois, M., K. A. Gilles, J. K. Hamilton, P. A. Rebes, and F. Smith. 1956. Colorimetric method for determination of sugars and related substances. Anal. Chem. 28:350-356. https://doi.org/10.1021/ ac60111a017. 
Eastridge, M. L., P. B. Bucci, and C. V. D. M. Ribeiro. 2009. Feeding equivalent concentrations of forage neutral detergent fiber from alfalfa hay, grass hay, wheat straw, and whole cottonseed in corn silage based diets to lactating cows. Anim. Feed Sci. Technol. 150:86-94

FAOSTAT. 2016. Food and Agriculture Data Centers, Crops Production. Food and Agriculture Organization of the United Nations, Rome, Italy. Accessed Jul. 7, 2016. http://www.fao.org/faostat/ en/\#data/QC.

Farmer, E. R., H. A. Tucker, H. M. Dann, K. W. Cotanch, C. S. Mooney, A. L. Lock, K. Yagi, and R. J. Grant. 2014. Effect of reducing dietary forage in lower starch diets on performance, ruminal characteristics, and nutrient digestibility in lactating Holstein cows. J. Dairy Sci. 97:5742-5753. https://doi.org/10.3168/jds.2014 $-7963$.

Ferraretto, L. F., A. C. Fonseca, C. J. Sniffen, A. Formigoni, and R. D. Shaver. 2015. Effect of corn silage hybrids differing in starch and neutral detergent fiber digestibility on lactation performance and total-tract nutrient digestibility by dairy cows. J. Dairy Sci. 98:395-405. https://doi.org/10.3168/jds.2014-8232.

Firkins, J. L. 1997. Effects of feeding non-forage fiber sources on site of fiber digestion. J. Dairy Sci. 80:1426-1437. https://doi.org/10 .3168/jds.S0022-0302(97)76072-7.

Fox, D. G., L. O. Tedeschi, T. P. Tylutki, J. B. Russell, M. E. Van Amburgh, L. E. Chase, A. N. Pell, and T. R. Overton. 2004. The Cornell Net Carbohydrate and Protein System model for evaluating herd nutrition and nutrient excretion. Anim. Feed Sci. Technol. 112:29-78.

Fustini, M., A. J. Heinrichs, A. Palmonari, and A. Formigoni. 2016. Farm characteristics and TMR particle size issues on Parmigiano Reggiano farms in Northern Italy. Prof. Anim. Sci. 32:869-873. https://doi.org/10.15232/pas.2016-01550.

Fustini, M., A. Palmonari, G. Canestrari, E. Bonfante, L. Mammi, M. T. Pacchioli, G. C. J. Sniffen, R. J. Grant, K. W. Cotanch, and A. Formigoni. 2017. Effect of undigested neutral detergent fiber content of alfalfa hay on lactating dairy cows: Feeding behavior, fiber digestibility, and lactation performance. J. Dairy Sci. 100:4475-4483. https://doi.org/10.3168/jds.2016-12266.

Ghasemi, E., G. R. Ghorbani, and M. Khorvash, 2016. Effect of feeding untreated straw or ensiled wheat straw treated with $\mathrm{NaOH}$, molasses and wheat grain on performance of lactating dairy cows. Animal Science Journal (Pajouhesh \& Sazandegi). 112:33-46.

Hall, M. B., and C. Herejk. 2001. Differences in yields of microbial crude protein from in vitro fermentation of carbohydrates. J. Dairy Sci. 84:2486-2493. https://doi.org/10.3168/jds.S0022 $-0302(01) 74699-1$.

Hooper, A. P., and J. G. Welch. 1985. Effects of particle size and forage composition on functional specific gravity. J. Dairy Sci. 68:11811188. https://doi.org/10.3168/jds.S0022-0302(85)80945-0.

Iranian Council of Animal Care. 1995. Guide to the Care and Use of Experimental Animals. Vol. 1. Isfahan University of Technology, Isfahan, Iran.

Kononoff, P. J. 2002. The effect of ration particle size on dairy cows in early lactation. PhD Thesis. Department of Animal Science, The Pennsylvania State University, Philadelphia.

Krizsan, S. J., and P. Huhtanen. 2013. Effect of diet composition and incubation time on feed indigestible neutral detergent fiber concentration in dairy cows. J. Dairy Sci. 96:1715-1726. https://doi .org/10.3168/jds.2012-5752.

Leonardi, C., and L. E. Armentano. 2003. Effect of quantity, quality, and length of alfalfa hay on selective consumption by dairy cows J. Dairy Sci. 86:557-564. 10.3168/jds.S0022-0302(03)73634-0.

Lock, A. L., C. L. Preseault, J. E. Rico, K. E. DeLand, and M. S. Allen. 2013. Feeding a C16:0-enriched fat supplement increased the yield of milk fat and improved conversion of feed to milk. J. Dairy Sci. 96:6650-6659. https://doi.org/10.3168/jds.2013-6892.

Lopes, F., K. Ruh, and D. K. Combs. 2015. Validation of an approach to predict total-tract fiber digestibility using a standardized in vitro technique for different diets fed to high-producing cows. J. Dairy Sci. 98:2596-2602. https://doi.org/10.3168/jds.2014-8665.
Mahjoubi, E., H. Amanlou, D. Zahmatkesh, M. G. Khan, and N. Aghaziarati. 2009. Use of beet pulp as a replacement for barley grain to manage body condition score in over-conditioned late lactation cows. Anim. Feed Sci. Technol. 153:60-67. https://doi.org/ 10.1016/j.anifeedsci.2009.06.009.

McCartney, D. H., H. C. Block, D. L. Dubeski, and A. J. Ohama. 2006. Review: The composition and availability of straw and chaff from small grain cereals for beef cattle in western Canada. Can. J. Anim. Sci. 86:443-455. https://doi.org/10.4141/A05-092.

Mertens, D. R. 1993. Kinetics of cell-wall digestion and passage in ruminants. Pages 535-571 in Forage Cell Wall Structure and Digestibility. H. G. Jung, D. R. Buxton, R. D. Hatfield, and J. Ralph, ed. American Society of Agronomy, Crop Science Society of America, Soil Science Society of America, Madison, WI.

Mertens, D. R. 2016. Using uNDF to predict dairy cow performance and design rations. Pages 12-19 in Proc. Four-State Dairy Nutrition and Management Conference, Dubuque, IA. Iowa State University.

Miller-Cushon, E. K., and T. J. DeVries. 2017. Feed sorting in dairy cattle: Causes, consequences, and management. J. Dairy Sci. 100:4172-4183.

Nair, J., D. Christensen, P. Yu, A. D. Beettie, T. McAllister, D. Damiran, N. Preston, L. Fuhr, and J. J. McKinnon. 2016. A nutritional evaluation of common barley varieties grown for silage by beef and dairy producers in western Canada. Can. J. Anim. Sci. 96:598-608. https://doi.org/10.1139/cjas-2016-0032.

Nasrollahi, S. M. 2011. Nutrition and Reproductive Challenges in Holstein Cow, 1st ed. Sepehr Publication Center, Tehran, Iran.

Nasrollahi, S. M., M. Imani, and Q. Zebeli. 2015. A meta-analysis and meta-regression of the effect of forage particle size, level, source, and preservation method on feed intake, nutrient digestibility, and performance in dairy cows. J. Dairy Sci. 98:8926-8939. https://doi .org/10.3168/jds.2015-9681.

Nasrollahi, S. M., M. Imani, and Q. Zebeli. 2016. A meta-analysis and meta-regression of the impact of particle size, level, source and preservation method of forages on chewing behavior and ruminal fermentation in dairy cows. Anim. Feed Sci. Technol. 219:144-158. https://doi.org/10.1016/j.anifeedsci.2016.06.012.

Nordlund, K. V., and E. F. Garrett. 1994. Rumenocentesis: A technique for the diagnosis of subacute rumen acidosis in dairy herds. Bov. Pract. 28:109-112.

NRC. 2001. Nutrient Requirements of Dairy Cattle. 7th rev. ed. Natl. Acad. Sci., Washington, DC.

Oba, M., and M. S. Allen. 1999. Evaluation of the importance of NDF digestibility: Effects on dry matter intake and milk yield of dairy cows. J. Dairy Sci. 82:589-596. https://doi.org/10.3168/jds.S0022 -0302(99)75271-9.

Pasha, T. N., E. C. Prigge, R. W. Russell, and W. B. Bryan. 1994. Influence of moisture content of forage diets on intake and digestion by sheep. J. Anim. Sci. 72:2455-2463. https://doi.org/10 $.2527 / 1994.7292455 x$.

Piccioli-Cappelli, F., J. J. Loor, C. J. Seal, A. Minuti, and E. Trevisi. 2014. Effect of dietary starch level and high rumen-undegradable protein on endocrine-metabolic status, milk yield, and milk composition in dairy cows during early and late lactation. J. Dairy Sci. 97:7788-7803. https://doi.org/10.3168/jds.2014-8336.

Poore, M. H., J. A. Moore, R. S. Swingle, T. P. Eck, and W. H. Brown. 1991. Wheat straw or alfalfa hay in diets with $30 \%$ neutral detergent fiber for lactating Holstein cows. J. Dairy Sci. 74:3152-3159.

Raffrenato, E., C. F. Nicholson, and M. E. Van Amburgh. 2019. Development of a mathematical model to predict pool sizes and rates of digestion of 2 pools of digestible neutral detergent fiber and an undigested neutral detergent fiber fraction within various forages. J. Dairy Sci. 102:351-364. https://doi.org/10.3168/jds.2018-15102.

Raffrenato, E., D. A. Ross, and M. E. Van Amburgh. 2018. Development of an in vitro method to determine rumen undigested aNDFom for use in feed evaluation. J. Dairy Sci. 101:9888-9900. https: //doi.org/10.3168/jds.2018-15101.

Reynolds, C. K., L. A. Crompton, and J. A. N. Mills. 2011. Improving the efficiency of energy utilisation in cattle. Anim. Prod. Sci. 51:6-12. https://doi.org/10.1071/AN10160. 
SAS Institute. 2002. User's Guide: Statistics. Version 9.1. SAS Inst. Inc., Cary, NC.

Schroder, U. J., and R. Staufenbiel. 2006. Invited review: methods to determine body fat reserves in the dairy cow with special regard to ultrasonographic measurement of back fat thickness. J. Dairy Sci. 89:1-14. https://doi.org/10.3168/jds.S0022-0302(06)72064-1.

Spanghero, M., P. Berzaghi, R. Fortina, F. Masoero, L. Rapetti, C. Zanfi, S. Tassone, A. Gallo, S. Colombini, and J. C. Ferlito. 2010. Technical note: Precision and accuracy of in vitro digestion of neutral detergent fiber and predicted net energy of lactation content of fibrous feeds. J. Dairy Sci. 93:4855-4859. https://doi.org/ 10.3168/jds.2010-3098.

Su, H., M. S. Akins, N. M. Esser, R. Ogden, W. K. Coblentz, K. F. Kalscheur, and R. Hatfield. 2017. Effects of feeding alfalfa stemlage or wheat straw for dietary energy dilution on nutrient intake and digestibility, growth performance, and feeding behavior of Holstein dairy heifers. J. Dairy Sci. 100:7106-7115. https://doi.org/10 .3168/jds.2016-12448

Suarez-Mena, F. X., G. I. Zanton, and A. J. Heinrichs. 2013. Effect of forage particle length on rumen fermentation, sorting and chewing activity of late-lactation and non-lactating dairy cows. Animal 7:272-278.

Teimouri Yansari, A., R. Valizadeh, A. Naserian, D. A. Christensen, P. Yu, and F. Eftekhari Shahroodi. 2004. Effects of alfalfa particle size and specific gravity on chewing activity, digestibility, and performance of Holstein dairy cows. J. Dairy Sci. 87:3912-3924. https: //doi.org/10.3168/jds.S0022-0302(04)73530-4.

Townshend, A. 1995. Encyclopedia of Analytical Science. Academic Press, London, UK.

Tyrrell, H. F., and J. T. Reid. 1965. Prediction of the energy value of cow's milk. J. Dairy Sci. 48:1215-1223. https://doi.org/10.3168/ jds.S0022-0302(65)88430-2.
Van Soest, P. J. 1994. Nutritional Ecology of the Ruminant. 2nd ed. Cornell Univ., Ithaca, NY.

Van Soest, P. J., J. B. Robertson, and B. A. Lewis. 1991. Methods for dietary fiber, neutral detergent fiber, and nonstarch polysaccharides in relation to animal nutrition. J. Dairy Sci. 74:3583-3597. https://doi.org/10.3168/jds.S0022-0302(91)78551-2.

Voelker, J. A., and M. S. Allen. 2003. Pelleted beet pulp substituted for high-moisture corn: 3. Effects on ruminal fermentation, $\mathrm{pH}$, and microbial protein efficiency in lactating dairy cows. J. Dairy Sci. 86:3562-3570. https://doi.org/10.3168/jds.S0022-0302(03)73961 $-7$.

Wang, B., S. Y. Mao, H. J. Yang, Y. M. Wu, J. K. Wang, S. L. Li, Z. M. Shen, and J. X. Liu. 2014. Effects of alfalfa and cereal straw as a forage source on nutrient digestibility and lactation performance in lactating dairy cows. J. Dairy Sci. 97:7706-7715. https://doi .org/10.3168/jds.2014-7961.

Wilson, R. C., T. R. Overton, and J. H. Clark. 1998. Effects of Yucca shidigera extract and soluble protein on performance of cows and concentrations of urea nitrogen in plasma and milk. J. Dairy Sci. 81:1022-1027. https://doi.org/10.3168/jds.S0022-0302(98)75664 -4 .

Wullepit, N., M. Hostens, C. Ginneberge, V. Fievez, G. Opsomer, D. Fremaut, and S. DeSmet. 2012. Influence of a marine algae supplementation on the oxidative status of plasma in dairy cows during the periparturient period. Prev. Vet. Med. 103:298-303. https:/ doi.org/10.1016/j.prevetmed.2011.09.007.

Zhu, L., C. Jones, Q. Guo, L. Lewis, C. R. Stark, and S. Alavi. 2016. An evaluation of total starch and starch gelatinization methodologies in pelleted animal feed. J. Anim. Sci. 94:1501-1507. https:// doi.org/10.2527/jas.2015-9822. 